\title{
AN IMPROVED INFANT BLOOD PRESSURE CUFF
}

\author{
I. A. SLOAN, M.B., CH.B., F.F.A.R.C.S. (ENG.), F.R.C.P.(C)
}

BECAuse of unsuitable equipment the blood pressure is often unobtainable in infants. Improvements can be effected by meeting the following requirements: (a) correct cuff width and size of inflation bag; $(b)$ an adequate but nonconstrictive fastening.

Robinow ${ }^{1}$ has shown that in infants with an arm circumference of 7.5 to $10 \mathrm{~cm}$. (up to about $9 \mathrm{~kg}$. in weight) a sphygmomanometer cuff $4 \mathrm{~cm}$. wide gives more accurate readings. An inflation bag which encircles the arm ensures greater accuracy.

"Velcro" fastenings have been found to be reliable and allow for proper adjustment of the cuff, whereas a long elastic rubber wrap-around band is easily applied too tightly and may then act as a tourniquet.

These features have been combined as follows: A commercially available latex rubber blood pressure cuff $14 \mathrm{~cm} . \times 4 \mathrm{~cm}$. wide has a $14 \mathrm{~cm}$. $\times 2.5$ strip of "Velcro" pile \#8200* machine stitched to the wrap-around armband. A $10 \mathrm{~cm}$. $\times 2.5 \mathrm{~cm}$. length of \#8180 Hook Velcro tape is machine stitched to the other
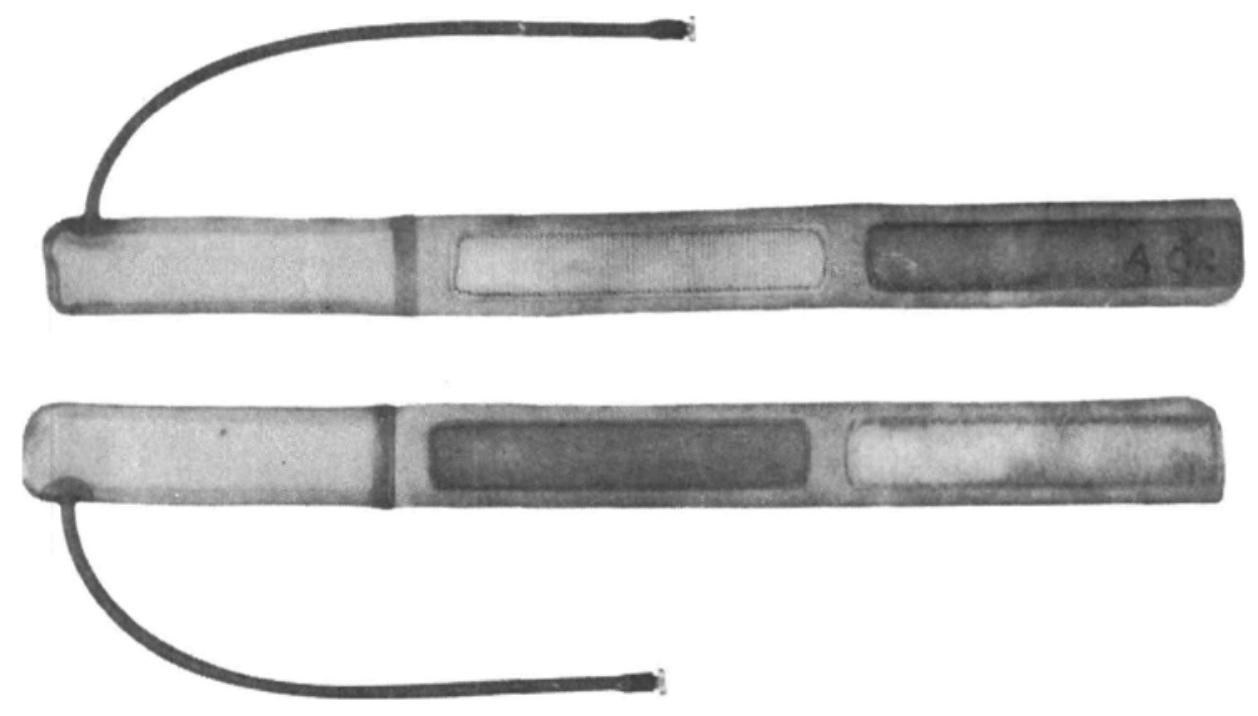

Figure 1. Front and back sides of the armband.

-Department of Anaesthesia, the Hospital for Sick Children, and University of Toronto. †Blood pressure cuff \#5637; Davol Rubber Co., Providence 2, Rhode Island, U.S.A.

†Velcro tape, B. C. Hollingshead, Ltd., 64 Gerrard Street East, Toronto 2, Ontario.

59

Can. Anaes. Soc. J., vol. 14, no. 1, January, 1967 


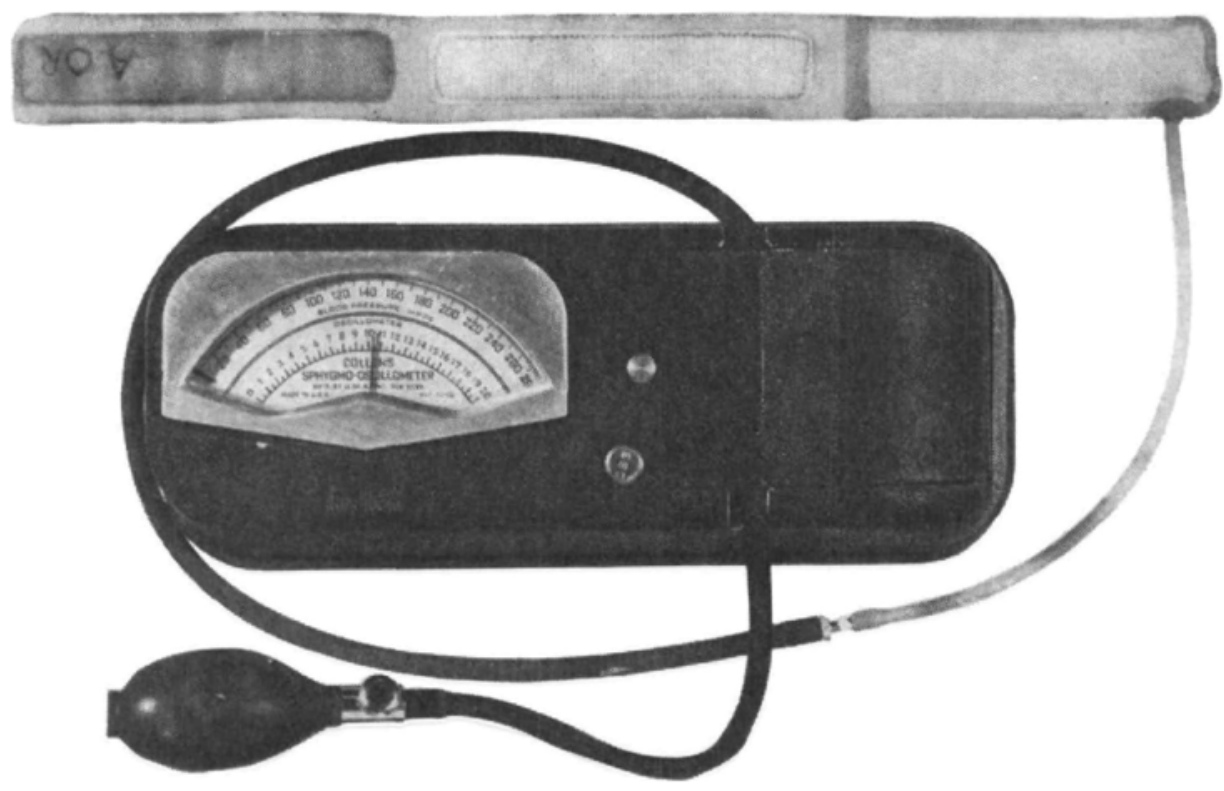

Figure 2

side of the armband as shown in Figure 1, and the excess length of armband is cut off.

Infant blood pressure cuffs modified in this way and used with a Collens Sphygmo-oscillometer (Fig. 2) have been in daily use in the Hospital for Sick Children, Toronto, for over five years and have proved very satisfactory.

Thanks are due to Mrs. Lynette Batty, R.N., who devised this modification.

Souvent, on ne peut pas prendre la tension artérielle chez les poupons à cause du matériel inadéquat à notre disposition. On peut assurer des améliorations en remplissant les exigences suivantes: $(a)$ un manchon de largeur et de grandeur appropriées; ( $b$ ) une fixation adéquate sans étreinte exagérée.

Robinow $^{1}$ a démontré que chez des poupons dont le tour du bras mesure de 7.5 à $10 \mathrm{~cm}$. (jusqu'au poids de 9 kilos environ) un manchon de sphygmomanomètre de $4 \mathrm{~cm}$. de largeur permet des lectures plus exactes. Un ballon gonflable qui encercle le bras assure une plus grande précision.

La fixation "Velcro" s'est avéré fiable et permet un ajustement adéquat du manchon, alors qu'une longue bande élastique circulaire peut facilement serrer trop et elle devient alors un tourniquet.

Voici comment nous avons associé ces caractéristiques: Un ballon en caoutchouc à pression artérielle, ballon qu'on trouve dans le commerce, ballon qui mesure $14 \mathrm{~cm} . \times 4 \mathrm{~cm}$. de large est fixé à une bande de "Velcro" de $14 \mathrm{~cm} . \times 2.5 \mathrm{~cm}$. \#8200 faufilé à la machine à la bande qu'on enroule autour du bras. Un ruban de "Velcro" \#8180 de $10 \mathrm{~cm} . \times 2.5 \mathrm{~cm}$. de long est cousu à la machine sur le coté 
opposé de la bande qu'on enroule autour du bras comme le démontre la Figure 1 et l'on coupe l'excédent de la bande.

Des appareils à pression pour poupons, appareils modifiés de cette façon et employés avec un Sphygmo-oscillometer Collens (Fig. 2), sont d'usage quotidien à l'hôpital des Enfants Malades de Toronto depuis plus de cinq ans et se sont avérés très satisfaisants.

\section{REFERENCE}

1. Robnnow, M. Accuracy of Determination of Blood Pressure in Children. Am. J. Dis. Child. 58: 102 (1939). 